九州大学学術情報リポジトリ

Kyushu University Institutional Repository

\title{
Design Parameter Optimization for Tillage Blade of Crank-type Rotavators considering Strength and Weight
}

Nam, Ju-Seok

Korea Institute of Machinery \& Materials

Moon, Sang-Gon

Korea Institute of Machinery \& Materials

Park, Sang-Hun

Department of Bio-Industrial Machinery Engineering, Chonbuk National University

Inoue, $\mathrm{Eij} \mathrm{i}$

Laboratory of Agricultural Machinery and Production Systems Design, Division of Bioproduction Environmental Sciences, Department of Agro-environmental Sciences, Faculty of Agriculture, Kyushu University

他

https://doi.org/10.5109/1564099

出版情報：九州大学大学院農学研究院紀要. 61 (1)，pp. 165-172，2016-02-29. Faculty of Agriculture, Kyushu University

バージョン：

権利関係 : 


\title{
Design Parameter Optimization for Tillage Blade of Crank-type Rotavators considering Strength and Weight
}

\author{
Ju-Seok NAM${ }^{1}$, Sang-Gon MOON ${ }^{1}$, Sang-Hun PARK ${ }^{2}$, Eiji INOUE, \\ Takashi OKAYASU and Dae-Cheol KIM ${ }^{2, *}$
}

\author{
Laboratory of Agricultural Machinery and Production Systems Design, Division of Bioproduction Environmental Sciences, \\ Department of Agro-environmental Sciences Faculty of Agriculture, \\ Kyushu University, FuKuoka, 812-8581, Japan \\ (Received November 11, 2015 and accepted November 19, 2015)
}

\begin{abstract}
This study conducted design parameter optimization for tillage blade of a crank-type rotavator $(45 \mathrm{~kW}$ rated power, eight blades). Load, stress, and mass of the blade were obtained from field tests and a commercial program, and design parameter optimization was carried out with them. Selected design parameters were the heights of front and rear ribs, and thickness of the blade. And objective function was minimizing the mass of the blade. Optimization for the nominal tillage blade was conducted considering two different cases of thickness profile: constant thickness of tillage blade in the length direction and inclined thickness. In addition, it was conducted in two different cases of safety factor to consider the changes of tillage load depending on the soil characteristics: higher safety factor on the stress than the nominal tillage blade and lower safety factor.

From the results of the optimization for the nominal tillage blade, the mass of the blade reduced by $3.2 \%$ under the same safety factor condition. And results of the optimizations with various conditions showed that higher safety factor increased the mass of the blade. The inclined blade also increased the mass of the blade to have the same safety factor. The results of the sensitivity analysis provided that the design parameter affected most on the stress and mass of the blade was thickness of the blade. Therefore, determining appropriate safety factor and thickness of the blade is important in designing the tillage blade.

Design parameters of this study do not affect on the surface area of the blade, which is the important influence factor for the tillage performance. Thus, the process used in this study will contribute to the design of tillage blade in minimizing the mass while having similar tillage performance. Further studies on optimization of the shape of the frame and optimization of geometrical structure of the blade will be needed.
\end{abstract}

Key words: crank-type, rotavator, optimal design, tillage blade, strength, weight

\section{INTRODUCTION}

Tillage operation is the agricultural preparation for crops cultivation, and it creates favorable environments for crop growth by improving air permeability and drainage of the soil (Canarache, 1991). Power operated tillage using tractors and rotavators is applied for most tillage operations (RDA, 2011). The most commonly used rotavator is the rotary-type which uses curved knife shaped (C-shape, L-shape, etc) tillage blade. Its rotavating depth is $100 \sim 200 \mathrm{~mm}$. The tilling pitch of the rotarytype rotavator is short, and the traction resistance significantly increases when the rotavating depth increases. For this reason, the rotary- type rotavator is not suitable for deep tillage, and there is a growing need for deep tillage to reclaim organics in orchards, green houses, and clearings as well as general arable land such as the farmland.

Plow-type and crank-type rotavators are used for deep tillage works. The plow-type rotavator uses plow shaped tillage blade, and crank-type rotavator uses shovel shaped tillage blade. Their rotavating depths are $300 \sim 400 \mathrm{~mm}$. The crank-type rotavator has merits of

\footnotetext{
Korea Institute of Machinery \& Materials, 156 Gajeongbuk-Ro , Yuseong-Gu, Daejeon, 305-343, Republic of Korea

Department of Bio-Industrial Machinery Engineering, Chonbuk National University, 567, Baekje-daero, Deokjin-gu, Jeonju-si, Jeollabuk-do, 54896, Republic of Korea

* Corresponding Author (E-mail: dckim12@jbnu.ac.kr)
}

higher soil pulverizing and inversion ratios, and lower average consumed power than the plow-type rotavator (Kim et al., 2013(b)). The crank-type rotavator is commercially available in some European countries such as Italy, and it cuts the soil into an aggregated structure (Cellicorea, 2008) which affects crop growth by better air permeability and moisture content in soils (Vittal et al., 1983; Varsa et al., 1997; Yoo et al., 2006).

The use of the crank-type rotavator has been growing in Korea, but little research on this type has been conducted. Only the basic research to identify the operating characteristics was carried out (NIAE, 2004; Nam et al. 2012(a); Nam et al, 2012(b); Kim et al., 2013(a); Kim et al., 2013(b)). For the rotary-type rotavator, theoretical and experimental methodology for efficient blade design have been established through active research: the effect of blade shape on consumed power and tillage characteristics (Salokhe et al., 1993; Choi and NahmGung, 2000; Chertkiattipol and Niyamapa, 2010), blade design using theory and analysis (Kushwaha and Zhang, 1998; Mouazen and Nemenyi, 1999; Abo-Elnor et al., 2004; Godwin and O'Dogherty, 2007; Mandal et al., 2014), etc. However, there has been little research on the tillage blade design for the crank-type rotavator. In order to use the cranktype rotavator efficiently, it is necessary to optimize the tillage blade design according to soil conditions. Because the shape and weight of the tillage blade are known to be the major factors which affect the economic aspect as 
well as power and tillage characteristics of the rotavator, the study on the tillage blade design optimization considering the shape and weight is needed.

This study conducted tillage blade optimization using shape related design parameters for a crank-type rotavator, to minimize the weight while maintaining the same level of tillage performance. Thickness and rib height of the tillage blade were set as design parameters, and changes of loading levels were considered to reflect work characteristics of the rotavator operating with various soils. The results of this study will be used for fundamental data to design the tillage blade of crank-type rotavators.

\section{MATERIALS AND METHODS}

The amount of load applied to the tillage blade should be calculated first for the purpose of this study. Tillage operation is made by interaction with the soil and tillage blade, and the soil has non-linear and plastic behavior. Thus, analytical method to derive the blade load needs plenty of time and the result will be inaccurate when the several variables are not be accurately modeled (Kushwaha and Zhang, 1998; Mouazen and Nemenyi, 1999; Abo-Elnor et al., 2004; Godwin and O'Dogherty, 2007). On the contrary, deriving the load on tillage blade experimentally costs a lot for experiment setting, but it produces relatively accurate results. This study measured actual load on the crank-type rotavator through field tests, and the designing optimization was carried out using that.

\section{FIELD TEST}

Rotavator, Tractor and test site (Kim et al., 2013(a))

A crank-type rotavator which having nominal rotavating depth of $300 \mathrm{~mm}$, rated power of $45 \mathrm{~kW}$, and eight blades was used for this study. The field test was carried out with the rotavator attached to a prime mover tractor. The tractor is four-wheel drive having rated engine power of $48 \mathrm{~kW}$, and rated engine speed of $2200 \mathrm{rpm}$. The driving gears comprise of 48 stages for both forward and backward directions, and Power Take-Off (PTO) have 2 gears (550 rpm at gear 1 and $733 \mathrm{rpm}$ at gear 2). The test site, a dried paddy field covered with weeds, was located in Sangwol-myeon, Nonsan-si, Chungnam province, Korea. Soil texture, moisture content, and soil strength were measured to identify physical properties of the test site. The soil texture was classified using the USDA method, and the moisture content was measured at randomly selected two different locations in the test site using the oven method. The soil strength was measured using a soil compaction meter (SC900, Spectrum Technology, E Plainfield, USA) at four different locations in the test site, and the measurement depths were five points below the surface, i.e. $0-25 \mathrm{~cm}$ with $5 \mathrm{~cm}$ intervals. The measurement results showed that the soil texture was loamy sand which was comprised of $74 \%$ sand, $25.2 \%$ silt and $0.8 \%$ clay. The average moisture content was $28.2 \%$, and soil strength was in the range of $140-$ $2,317 \mathrm{kPa}$.

\section{Test conditions and results}

The crank-type rotavator used for deep tillage work has a large maximum work load. Working with high speed consumes high power which results in shut down of the tractor, therefore, the tillage operation should be done with relatively low speed. Driving speed of the tractors used by domestic farmers are 1-2 km/h (driving gear L2), and gear 1 is mainly used for the PTO. Thus, tillage work was carried on with conditions used by most farmers (driving gear L2 and PTO gear 1), and torque of PTO shaft was measured with a torque meter attached on the PTO shaft (Kim et al., 2013(b)). Tillage length was 15 m, and the tillage work was repeated twice under the same conditions. The sampling frequency of the data collection device was determined by $600 \mathrm{~Hz}$ not to influence on the tractor engine speed, PTO speed, and rotational speed of tillage blade. Figure 1 shows the tillage operation using the crank-type rotavator.

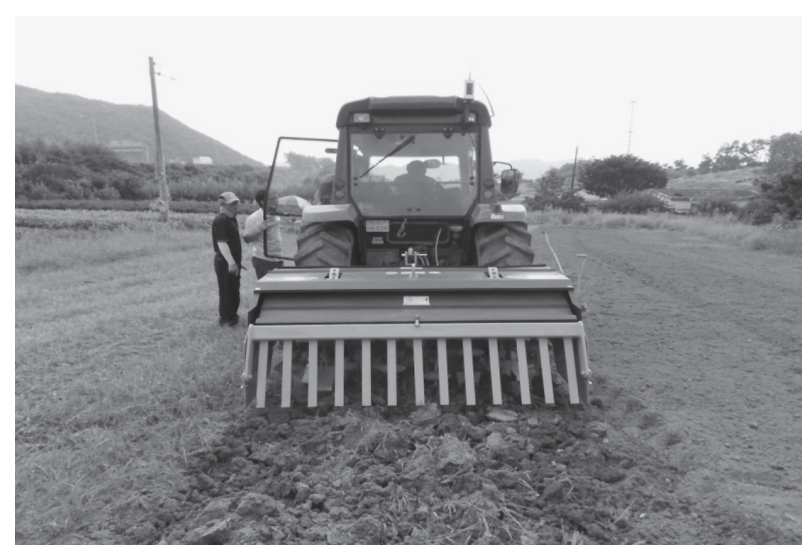

Fig. 1. A view of tillage operation using the crank-type rotavator.

Figure 2 provides the shape of the measured torque of PTO shaft. Tillage load is the highest when the blade contacts with the soil surface to enter into the subsoil (Choi and NahmGung, 2000). The initial contact of blade with the soil surface is made for a brief moment, so it could be considered as an impact load. The load on Figure 2 represents impact load by eight blades when they enter into the subsoil sequentially. Different magnitude of impact load occurred depending on the blade, and this resulted in periodic torque of PTO shaft. The blade location having the maximum torque would be changed according to the soil and blade characteristics.

The period of the measured torque signal was 0.53 sec. which was longer than the rotational period of the tillage blade (0.34 sec.) by $56 \%$. This difference was caused by friction in a mechanical connection between PTO shaft and tillage blade as well as the reaction force between the blade and the soil.

Parameter optimization for the blade which had the maximum load is the most effective; therefore, the maximum measured torque was used as the representative value of tillage load. Transmission mechanism comprised of two spur gear pairs is placed between the PTO shaft and the blade. The PTO speed decreases at the first gear 
pair, and increases at the second gear pair. The PTO torque shows the reverse tendency from the PTO speed at each gear pair. Table 1 shows the number of gear teeth for each gear pair. When the power transmission efficiency of each gear pair is assumed to be $97 \%$, crank shaft torque of the blade can be calculated from equation (1) using the PTO shaft torque and number of gear teeth of each gear pair. Average maximum PTO torque measured from two tillage works was $800 \mathrm{Nm}$, so the crank shaft torque was $2561 \mathrm{Nm}$.

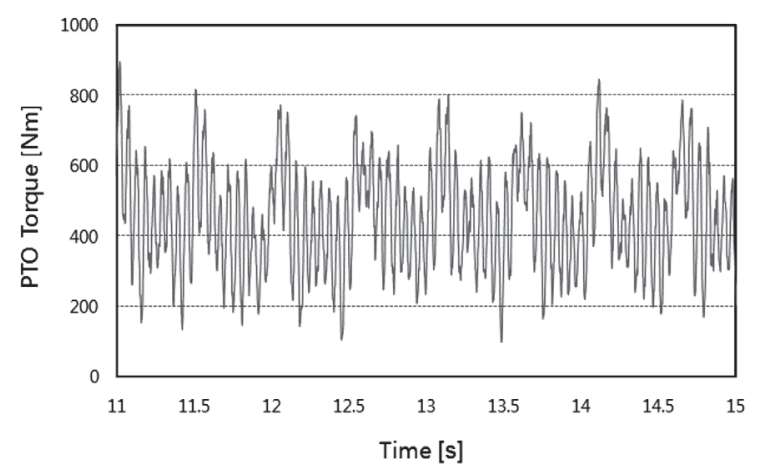

Fig. 2. PTO torque of the crank-type rotavator during tillage operation.

Table 1. Number of gear teeth for each gear pair

\begin{tabular}{ccc}
\hline Gear pair & Pinion & Wheel \\
\hline 1 & 14 & 16 \\
2 & 9 & 35 \\
\hline
\end{tabular}

$$
\mathrm{T}_{\mathrm{c}}=0.97^{2} \times \frac{14}{16} \times \frac{35}{9} \mathrm{~T}_{\mathrm{p}}
$$

Where, $\mathrm{T}_{c}$ : crank shaft torque, $\mathrm{Nm}$

$\mathrm{T}_{\mathrm{p}}$ : PTO shaft torque, Nm

\section{LOAD AND STRESS OF THE TILLAGE BLADE}

The load on the blade is generally concentrated in the lower part of the tillage blade (Shmulevich et al., 2007). Lower part of the crank-type rotavator's tillage blade contacts with the soil surface at the very first, therefore, it can be assumed that all the impact loads is applied to the lower part the blade. In practice, for the crank-type rotavator used for a long time, the paint of the lower part of the blades has been peeled off first (Figure 3). Thus, the lower part of the blades was set as loading surface, and components of the single tillage blade system are shown on Figure 4.

A commercial dynamic analysis program (RecurDyn, 2012) was used to calculate the normal force added on the loading surface to have 2,561 Nm of the crank shaft torque. The crank-type rotavator was modeled as an actual size, and constraints were determined considering the actual operating mechanism. In addition, driving speed of the tractor and the rotational speed of the blade were reflected on the analysis. Figure 5 shows the joint and loading conditions for the analysis.

The crank-type rotavator uses eight blades which are classified two different types according to the width of the lower part (Figure 6). Middle two blades are wider than the side six blades. Height of loading surface is the same in all eight blades by $30 \mathrm{~mm}$. Load on the blade is generally proportional to the height and width of the blade loading surface (Kushwaha and Zhang, 1998;

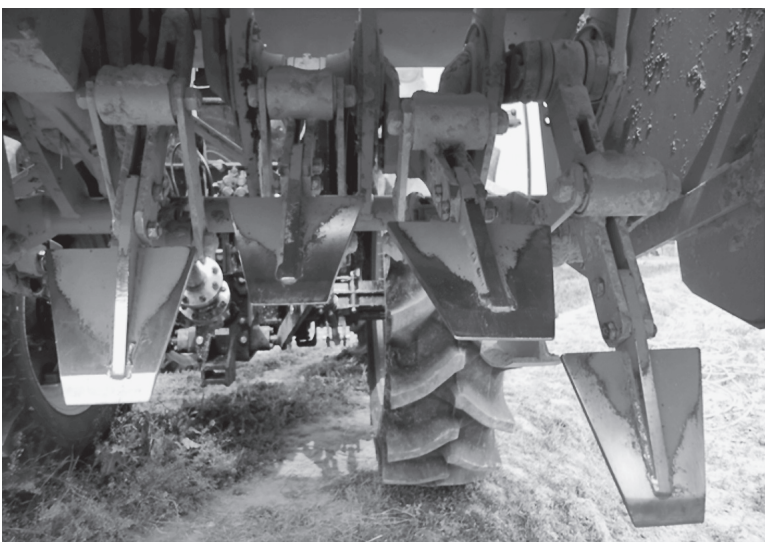

Fig. 3. Tillage blades used for a long time of tillage operation.

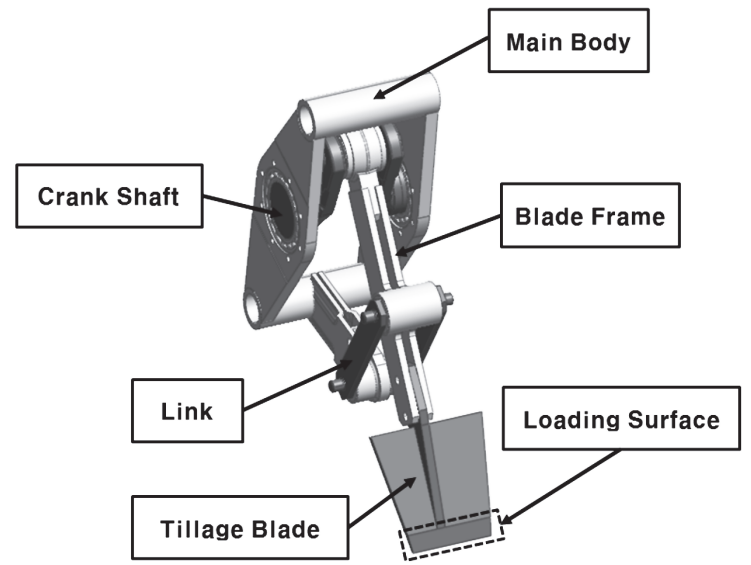

Fig. 4. Components of a single tillage blade system.

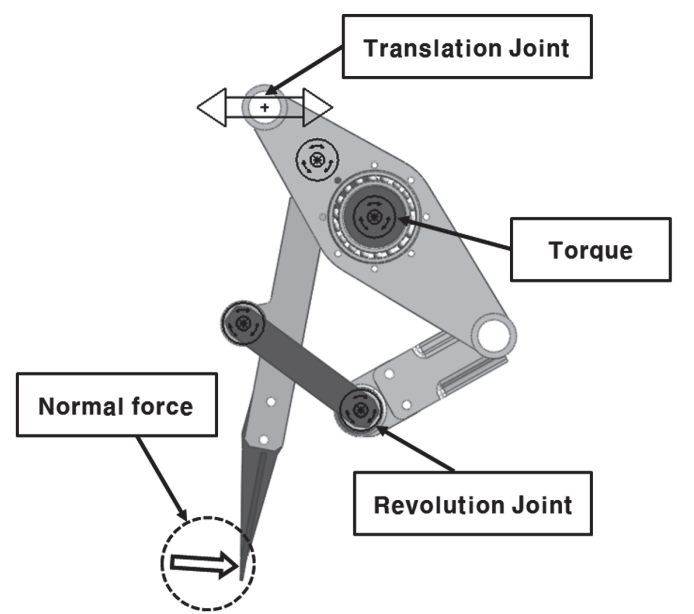

Fig. 5. Joint and loading conditions for the dynamic analysis. 
Godwin and O'Dogherty, 2007); therefore, it can be assumed that 2,561 Nm of the crank shaft torque which calculated from the field test is occurred from the middle blades. Thus, middle blades are selected as a nominal tillage blade for the parameter optimization.

From the dynamic analysis, the normal force which added to the loading surface of the nominal tillage blade was 10247 N. A commercial finite element analysis program (Ansys, 2013) was used to calculate equivalent stress generated when $10247 \mathrm{~N}$ of the normal force is applied to the blade loading surface. The mesh size was $5 \mathrm{~mm}$, the mesh shape was hexahedron, and a fixed support was applied to the bolted joint parts (Figure 7). From the stress analysis result, the maximum equivalent stress on the nominal tillage blade was occurred on the upper side of the front rib, and the magnitude was 423.6 MPa (Figure 8). Tensile yield strength of the nominal tillage blade made with $\mathrm{S} 45 \mathrm{C}$ is $490 \mathrm{MPa}$, so the safety factor for the stress is 1.16 .

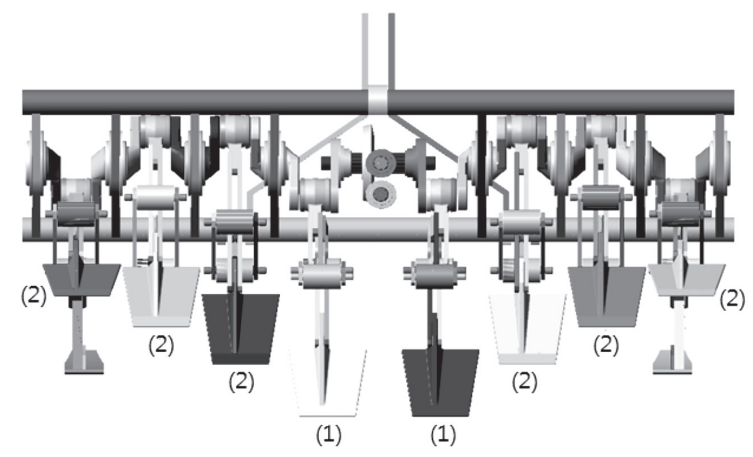

(a) Layout of eight blades.

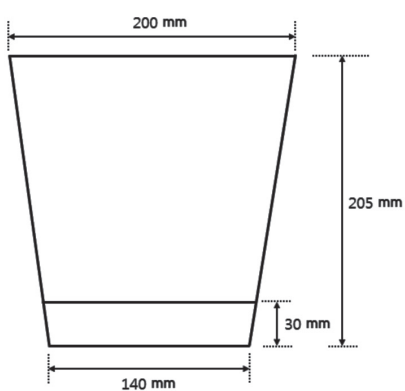

(b) Tillage blade shape: (1)

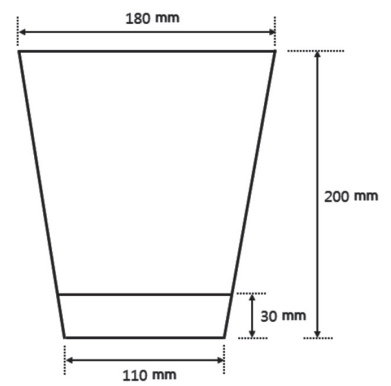

(c) Tillage blade shape: (2)

Fig. 6. Shape of tillage blades for the crank-type rotavator.
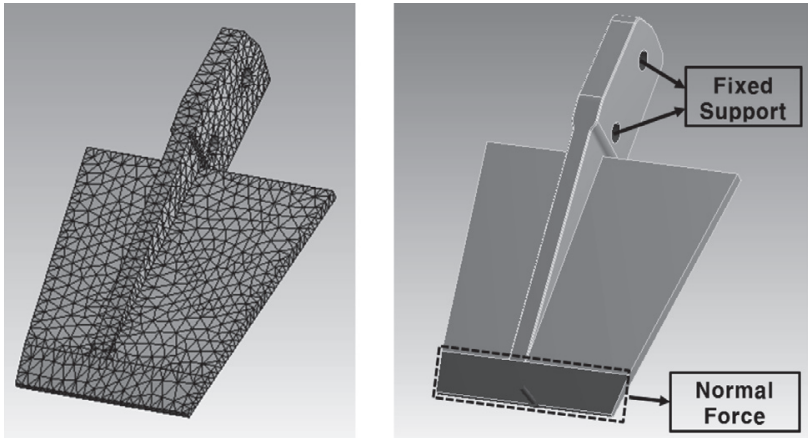

Fig. 7. Mesh shape and constraints for the stress analysis.

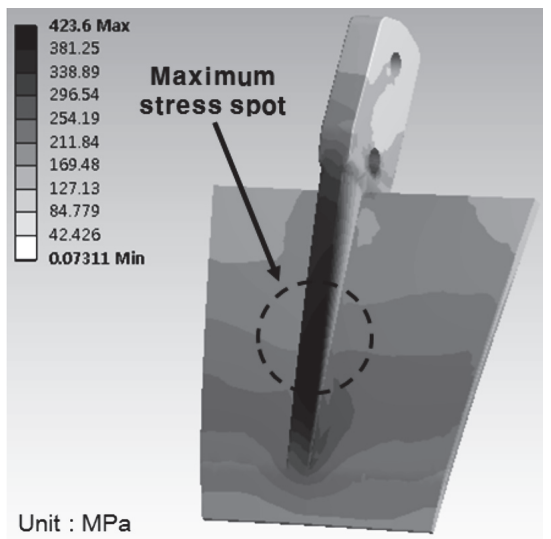

Fig. 8. Equivalent stress contour of the nominal tillage blade.

\section{PARAMETER OPTIMIZATION OF TILLAGE BLADE}

Conditions for parameter optimization

Detailed front and side views of the nominal tillage blade is shown on Figure 9. Thickness of the blade is $8 \mathrm{~mm}$, and loading surface thickness decreases from top $(8 \mathrm{~mm})$ to bottom $(4 \mathrm{~mm})$. The heights of front rib and rear rib of the starting part are $30 \mathrm{~mm}$ and $16 \mathrm{~mm}$, respectively, and it decreases to 0 on the loading surface. Thickness of the front rib and rear rib is $14.2 \mathrm{~mm}$.

The factor affecting directly on the tillage load and
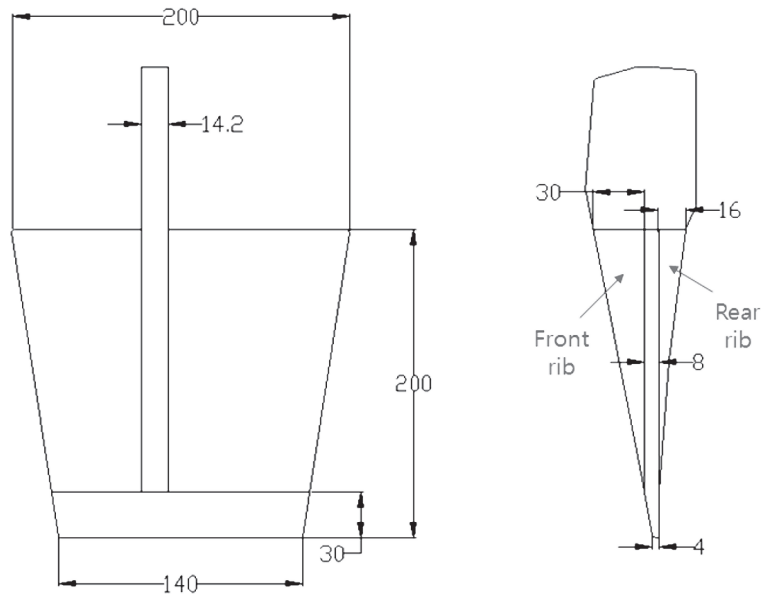

Fig. 9. Detailed views of the nominal tillage blade (unit: mm) 


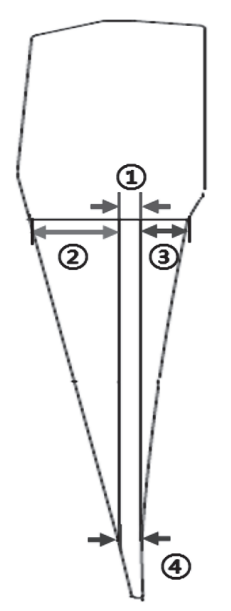

Fig. 10. Design parameters of tillage blade.

(1) start of thickness (SOT), (2) front rib height (FRH),

(3) rear rib height (RRH), (4) end of thickness (EOT)

performance is surface area of the blade. When the surface area is changed, the blade load should be recalculated through experiment and analysis using the changed blade. The heights of the front and rear ribs and thickness of the blade were set as design parameters in this study, because they do not affect the surface area of blade. In this case when the parameters are changed, the blade surface area does not change; as a result, load on the blade and tillage characteristics are not changed.

Objective function of the parameter optimization was set to minimize the weight of the blade. The optimized solution was obtained by changing the parameters within the range of $\pm 25 \%$ from value of the nominal tillage blade (Figure 10 and Table 2). Optimization for the nominal tillage blade was conducted considering two different cases of thickness profile: constant thickness of tillage blade in the length direction (type I) and inclined thickness (type II) (Figure 11). In addition, optimization to satisfy the objective function was carried on in two dif-

Table 2. Ranges of design parameters for the optimization

\begin{tabular}{ccccc}
\hline Value & SOT, mm & EOT, mm & FRH, mm & RRH, mm \\
\hline Lower & 6 & 6 & 27 & 13 \\
Current & 8 & 8 & 30 & 16 \\
Upper & 10 & 10 & 33 & 19 \\
\hline
\end{tabular}

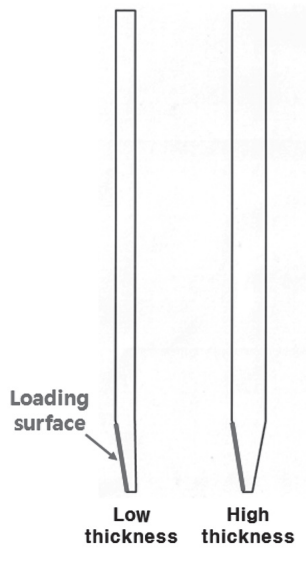

(type I )

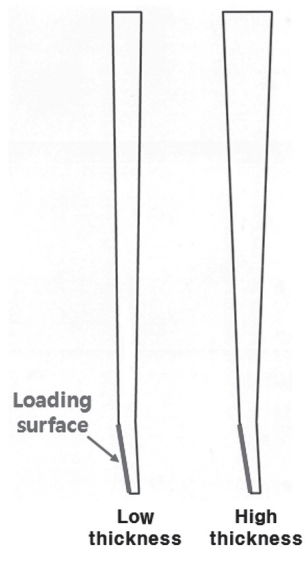

(type II)

Fig. 11. Tillage blade shapes according to the thickness type.

ferent cases of safety factor to consider the changes of tillage load depending on the soil characteristics: higher safety factor (1.4) on the stress than the nominal tillage blade and lower safety factor (1.0). Tillage blade conditions for optimization are shown in Table 3. Case 1 represents the nominal tillage blade, and cases 2 and 3 are the conditions of increasing and decreasing safety factor from the nominal tillage blade, respectively. Also, cases 4 and 5 represent inclined thickness and changed safety factor. When the inclined thickness was applied, the end of thickness (EOT) is fixed, and only the start of thickness (SOT) is set as the thickness related design parameter.

\section{Optimization method and results}

A commercial program EasyDesign (IDO, 2015) was used for this study to solve an optimization problem. It is a sequential approximate optimization tool based on the progressive meta-model techniques (Kim et al., 2014). Convergence range of the objective function to find optimized solution was set to $1 \%$. In other words, when the difference in the value of the objective parameter (blade weight) for the current condition is less than $1 \%$ compared to the previous condition, the optimized solution is considered to be obtained and terminated the analysis.

Table 4 shows the analysis conditions to seek the optimized solution for case 1 . Numbers 1 to 5 represent the basic analysis conditions reflecting the set deviation

Table 3. Tillage blade conditions to conduct parameter optimization

\begin{tabular}{|c|c|c|c|c|c|c|c|}
\hline Case & SOT, mm & EOT, mm & FRH, mm & $\mathrm{RRH}, \mathrm{mm}$ & $\begin{array}{c}\text { Safety } \\
\text { factor (S.F.) }\end{array}$ & $\begin{array}{c}\text { Thickness } \\
\text { type }\end{array}$ & Remarks \\
\hline 1 & 8 & 8 & 30 & 16 & 1.16 & type I & Nominal blade \\
\hline 2 & 8 & 8 & 30 & 16 & 1.4 & type I & Higher S.F. \\
\hline 3 & 8 & 8 & 30 & 16 & 1.0 & type I & Lower S.F. \\
\hline 4 & 8 & 7 (fixed) & 30 & 16 & 1.4 & type II & Sloped thickness, higher S.F. \\
\hline 5 & 8 & 6 (fixed) & 30 & 16 & 1.0 & type II & Sloped thickness, lower S.F. \\
\hline
\end{tabular}


range, and numbers 6 and 7 are analysis conditions carried sequentially to find the optimal solution. Equivalent stress contours on the blade are shown in Figure 12. Stress distributions on the blade were changed based on the size of the design parameters. The optimal solution was obtained in case 7 in which the blade thickness decreased and the heights of front and back ribs increased compared to the nominal tillage blade. Applying this shape, the weight was reduced by $3.2 \%$ from $2.5 \mathrm{~kg}$ to $2.42 \mathrm{~kg}$ under the same safety factor condition.

The optimal solutions for cases $2-5$ were calculated by applying the same process with case 1 . Tables 5 and 6

Table 4. Analysis conditions for case 1

\begin{tabular}{ccccccc}
\hline Number & SOT, mm & EOT, mm & FRH, mm & RRH, mm & Mass, kg & Safety factor \\
\hline 1 & 10 & 10 & 27 & 19 & 3.01 & 1.49 \\
2 & 10 & 10 & 33 & 13 & 3.01 & 1.51 \\
3 & 6 & 6 & 33 & 19 & 2.06 & 0.87 \\
4 & 6 & 6 & 27 & 13 & 1.94 & 0.73 \\
5 & 8 & 8 & 30 & 16 & 2.51 & 1.16 \\
6 & 7.6 & 7.6 & 33 & 16.9 & 2.44 & 1.16 \\
7 & 7.5 & 7.5 & 33 & 17.7 & 2.42 & 1.16 \\
\hline
\end{tabular}

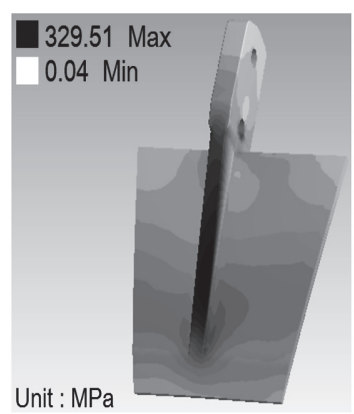

(a) No. 1

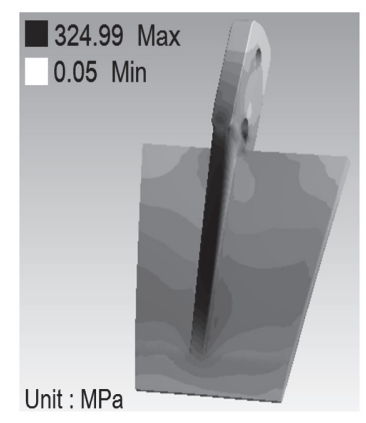

(b) No. 2

(e) No. 5

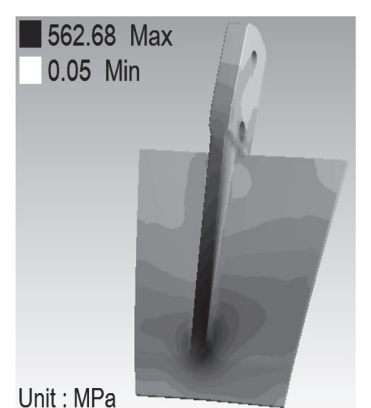

(c) No. 3

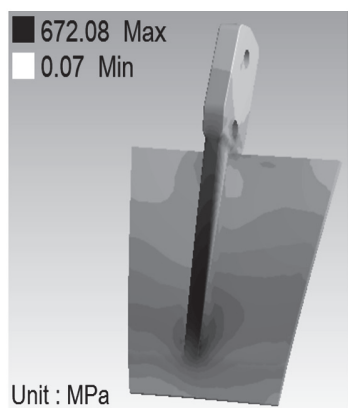

(d) No. 4
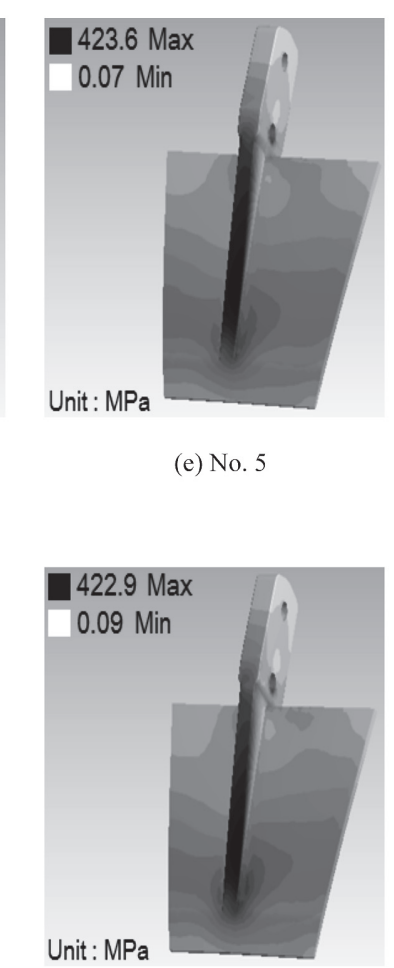

(g) No. 7

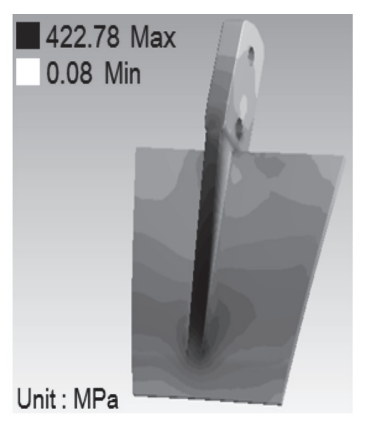

(f) No. 6

Fig. 12. Equivalent stresses occurred at each analysis condition for case 1 . 
Table 5. Optimized solution for each case

\begin{tabular}{crcccc}
\hline Case & SOT, mm & EOT, mm & FRH, mm & RRH, mm & Safety factor \\
\hline 1 & 7.5 & 7.5 & 33.0 & 17.7 & 1.16 \\
2 & 8.6 & 8.6 & 33.0 & 19.0 & 1.39 \\
3 & 6.9 & 6.9 & 32.6 & 16.1 & 1.00 \\
4 & 12.0 & 7.0 & 33.0 & 19.0 & 1.39 \\
5 & 8.5 & 6.0 & 32.0 & 19.0 & 1.00 \\
\hline
\end{tabular}

Table 6. Mass changes for each case after the parameters optimization

\begin{tabular}{cccc}
\hline Case & Mass of original blade, $\mathrm{kg}$ & Mass of optimized blade, $\mathrm{kg}$ & Change, $\%$ \\
\hline 1 & 2.50 & 2.42 & -3.2 \\
2 & 2.50 & 2.71 & +8.4 \\
3 & 2.50 & 2.25 & -10.0 \\
4 & 2.37 & 2.92 & +23.2 \\
5 & 2.24 & 2.35 & +4.9 \\
\hline
\end{tabular}

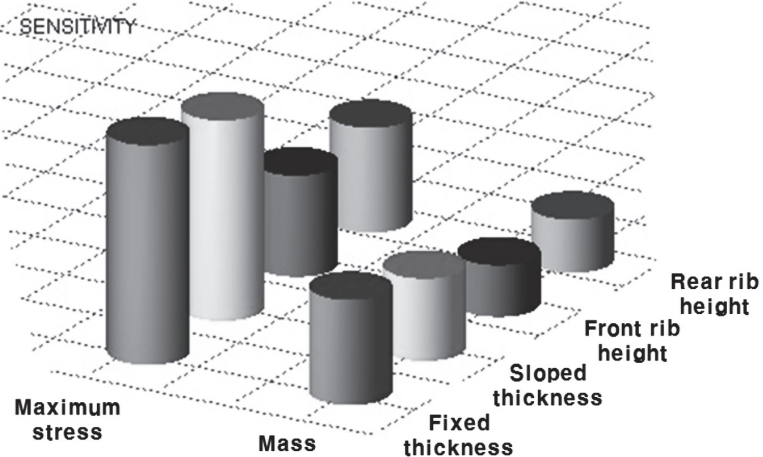

Fig. 13. Sensitivity of each design parameter against stress and mass of tillage blade.

show the sizes of the optimized design parameters and mass changes of the blade for the entire cases, respectively. When the safety factor decreased, the sizes of the design parameters and mass of the blade decreased. On the contrary, when the safety factor increased, the sizes of the design parameters and mass of the blade increased. The blade having constant thickness (type I) had smaller mass than the one having inclined thickness (type II) under the same safety factor condition. This is because the optimized solution for inclined thickness condition had small EOT, which results in the significantly increased SOT to satisfy the safety factor condition. Condition for smallest mass of the blade was case 3 which had constant thickness and low safety factor. This case reduced the mass by $10 \%$. In some cases, depending on the size of the safety factor and the shape of thickness profile, the mass of optimized blade increased compared to the initial blade. Therefore, it can be known that choosing appropriate safety factor and thickness is important in designing the tillage blade.

Figure 13 provides the results of the sensitivity analysis for each design parameter. The factor affected most on the maximum stress and mass of the blade was thick- ness of the blade. Heights of the front rib and rear rib showed a similar influence each other.

\section{SUMMARY AND CONCLUSIONS}

This study was on the design parameter optimization for the tillage blade of the crank-type rotavator. A cranktype rotavator with eight blades and rated power of 45 $\mathrm{kW}$ was used for this study. Through field tests using a prime mover tractor, torque on the tractor PTO shaft was measured. And load, stress, and mass of the blade were derived from a commercial program. After setting heights of front and rear ribs, and thickness of the blade for the design parameters, the conditions to minimize mass of the blade were examined by changing the parameters in the range of $\pm 25 \%$ deviation from the value of the nominal blade. Selected design parameters do not affect the surface area of the blade; therefore, it could be assumed that load on the blade and tillage characteristics are not changed.

Optimization for the nominal tillage blade was conducted considering two different cases of thickness profile: constant thickness of tillage blade in the length direction and inclined thickness. In addition, it was conducted in two different cases of safety factor to consider the changes of tillage load depending on the soil characteristics: higher safety factor on the stress than the nominal tillage blade and lower safety factor.

Stress distributions on the blade were changed based on the sizes of the design parameters, and it also showed a difference in the size of the maximum stress. Applying the optimized parameters for the nominal blade, the mass of the blade reduced by $3.2 \%$ from $2.5 \mathrm{~kg}$ to $2.42 \mathrm{~kg}$ under the same safety factor condition. Optimized parameters on the various conditions were also obtained. When the safety factor decreased, mass of the blade decreased. On the contrary, when the safety factor increased, mass of the blade increased. The blade having constant thickness had smaller mass than the one having inclined thick- 
ness under the same safety factor condition. Thus, condition of constant thickness and low safety factor showed the biggest mass reduction effect.

The results of the sensitivity analysis provide that the factor affected most on the maximum stress and mass of the blade was the blade thickness. Heights of the front rib and rear rib showed a similar influence each other. The mass of optimized blade even could be larger than the initial blade depending on the level of safety factor and blade thickness. Therefore, determining appropriate safety factor and thickness of the blade is important in designing the tillage blade.

The process used in this study will contribute to the design of tillage blade in terms of minimizing the mass while having a similar tillage performance.

\section{REFERENCES}

Abo-Elnor, M., R. Hamilton and J. T. Boyle. 2004. Simulation of soil-blade interaction for sandy soil using advanced 3D finite element analysis. Soil \& Tillage Research 75: 61-73

Ansys. 2013. Ansys mechanical user's guide. Ansys, Inc., Pennsylvania, USA

Canarache, A. 1991. Factors and indices regarding excessive compactness of agricultural soils. Soil \& Tillage Research 19: $145-164$

Cellicorea. 2008. Application of crank-type rotavator. Available at: www.cellicorea.com.

Chertkiattipol, S and T. Niyamapa. 2010. Variations of torque and specific tilling energy for different rotary blades. International Agricultural Engineering Journal 19(3): 1-14

Choi, C. H and M. J. NahmGung. 2000. Load measurement of tractor on field performance. Proceedings of the KSAM 2000 summer conference $\mathbf{2 5}(0)$ : 29-34

Godwin, R. J and M. J. O'Dogherty. 2007. Integrated soil tillage force prediction models. Journal of Terramechanics 44: 3-14

IDO. 2015. EasyDesign Version 3.0 User's Manual. Institute of Design Optimization, Inc., Seongnam, Korea

Kim, D. C., J. S. Nam, M. H. Kim, J. S. Choe, E. Inoue, T. Okayasu and D. C. Kim. 2013(a). Analysis of the tillage and power consumption characteristics of a crank-type rotavator according to the tillage blade shape. Journal of the Faculty of Agriculture Kyushu University 58(2): 319-328

Kim, M. H., J. S. Nam and D. C. Kim. 2013(b). Comparison of tillage and loads characteristics of three types of rotavators: rotary-type, crank-type, and plow-type. Journal of Biosystems Engineering 38(2): 73-80 (in Korea)

Kim, M. S., Kang, D. O and Heo, S. J. 2014. Innovative design optimization Strategy for the automotive industry. International Journal of Automotive Technology 15 (2): 291-301

Kushwaha, R. L and Z. X. Zhang. 1998. Evaluation of factors and current approaches related to computerized design of tillage tools: a review. Journal of Terramechanics 35: 69-86

Mandal, S., B. Bhattacharyya, S. Mukherjee and P. Chattopadhyay. 2014. Use of CAD tool for design and development of ratavator blade. Middle-East Journal of Scientific research 20(2): 171177

Mouazen, A. M and M. Nemenyi. 1999. Tillage tool design by the finite element method: part 1. finite element modelling of soil plastic behaviour. Journal of Agricultural Engineering Research 72: $37-51$

Nam, J. S., D. C. Kim, M. H. Kim and D. C. Kim. 2012(a). Tillage Characteristics Estimation of Crank-type and Rotary-type Rotavator by Motion Analysis of Tillage Blades. Journal of Biosystems Engineering 37(5): 279-286 (in Korea)

Nam, J. S., D. S. Kang, Y. S. Kang, K. U. Kim and D. C. Kim. 2012(b). Comparison of work performance of crank-type and rotary-type rotavators in Korean farmland conditions. Journal of Biosystems Engineering 37(3): 140-147 (in Korea)

NIAE. 2004. Experimental and research report. National Institute of Agricultural Engineering, Jeonju, Korea

RDA. 2011. A Study utilization of agricultural machinery and mechanization ratio. Rural Development Administration, Jeonju, Korea

RecurDyn. 2012. RecurDyn/Solver theoretical manual. FunctionBay, Inc., Seongnam, Korea

Salokhe, V. M., M. H. Miah and M. Hoki. 1993. Effect of blade type on power requirement and puddling quality of a rotavator in wet clay soil. Journal of Terramechanics 30(5): 337-350

Shmulevich, I., Z. Asaf and D. Rubinstein. 2007. Interaction between soil and a wide cutting blade using the discrete element method. Soil \& Tillage Research 97: 37-50

Varsa, E. C., S. K. Chong, J. O. Aboaji, D. A. Farquhar and F. J. Olsen 1997. Effect of deep tillage on soil physical characteristics and corn (Zea mays L.) root growth and production. Soil \& Tillage Research 43: 219-228

Vittal, K. P. R., K. Vijayalakshmi and U. M. B. Rao. 1983. Effect of deep tillage on dryland crop production in red soils of india Soil \& Tillage Research 3: 377-384

Yoo, C. H., J. H. Ryu, C. H. Yang, T. K. Kim, S. W. Kang, J. D. Kim and K. Y. Jung. 2006. Influence of Diagnostic Fertilization and Subsoil Breaking on Soil Physico-chemical Properties in Direct Seeding of Rice on Flooded Paddy Surface. Journal of Korean Society of Soil Science and Fertilizer 39(6): 334-338 